\title{
Degradation of Tryptophen Oxygenese
}

In Viwo and In Vitro*

The MOTICE

Thls roport wat prepaced ac an aceounl of work spensorad by ite Unitiod States Government. Neither the Uniled stales nor the United States Atomis Enesgy Commtation, nor buy of thatr andoyess, nor any of the' contrictocs, subcontractors, of their amployees?

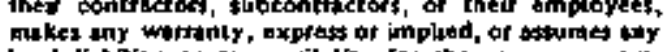
lopd linblily of repondiblfiy fot the accurncy, com. plesentes of usefulates of any informalion, opparalus. product of process dustoted, of repreatits that is val would not infriate privelely owned mats. 


\section{DISCLAIMER}

This report was prepared as an account of work sponsored by an agency of the United States Government. Neither the United States Government nor any agency Thereot, nor any of their employees, makes any warranty, express or implied, or assumes any legal liability or responsibility for the accuracy, completeness, or usefulness of any information, apparatus, product, or process disclosed, or represents that its use would not infringe privately owned rights. Reference herein to any specific commercial product, process, or service by trade name, trademark, manufacturer, or otherwise does not necessarily constitute or imply its endorsement, recommendation, or favoring by the United States Government or any agency thereof. The views and opinions of authors expressed herein do not necessarlly state or reflect those of the United States Government or any agency thereof. 


\section{DISCLAIMER}

Portions of this document may be illegible in electronic image products. Images are produced from the best available original document. 
Jeanne B. Lił and $W$. Eugene Knox

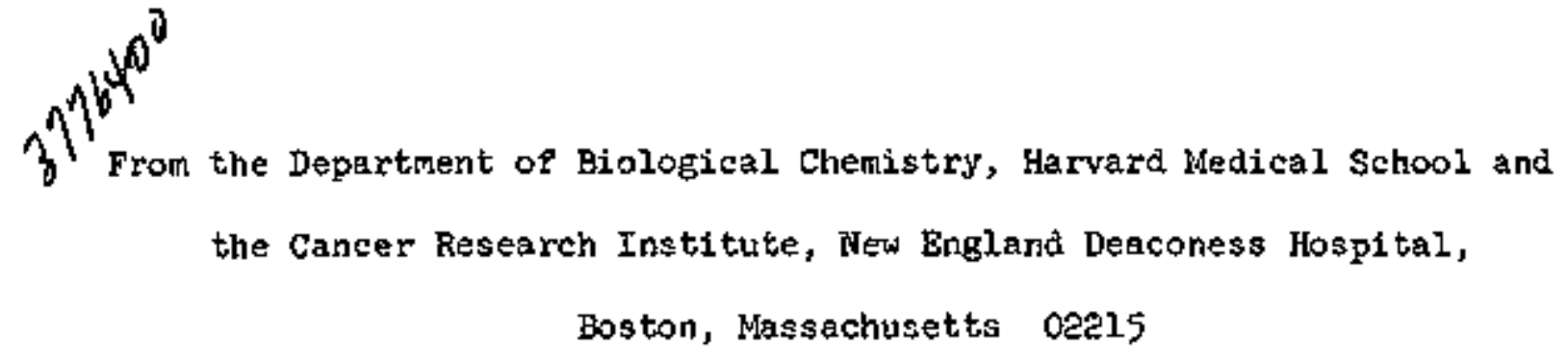


Running title: Degradation of tryptophan oxygenase 


\section{, SUMMARY}

The loss of tryptophan oxygenase from rat livers after induction by hydrocortisone treatment was studied in living rats, isolated perfused livers, liver slices and cell-free preparations of these livers. Measurements of the enzyme by its activity and as an antigen were parallel except for apparently non-specific inactivations in some incubations of cell-free preparations and the temporary, early appearance of a catalytically inactive antigen during accumulation of the enzyme after hydrocortisone treatment. The enzyme was lost at similar rates in all of the systems studied, including cell-free soluble fractions of liver. In all systems, the antigen was preserved by the substrate analog, cy-methyltryptophan. The rate of loss was proportional to the concentration of the enzyne and was the sane for added or endogenous enzyme and the same in non-induced or induced liver preparations. Labeled, purifted enzyme added to cell-free preparations was used to demonstrate that the loss of antigenio material was not signisicantly associated with its proteolysis to small fragments. The results are compatible with an initial step in the degradation of this enzyme that is akin to a denaturation, and which can be prevented by combination of the protein with its substrate. 
The occurrence of intracellular protein degradation as part of the turnover of proteins in mammals has been known since 1942 (1). This important aspect of protein metabolism has been neglected in comparison with the interest shown in protein synthesis. Most of the experimental data available concerns the role of protein degradation in determining the levels of enzymes in animal tissues, and in this connection, the rates of turnover have been measured for a number of rat proteins $(2,3)$. However, there is little known about the actual mechanien of intracellular protein degradation, or about the nature of the proteolytic-reactions involved.

Rat liver tryptophan oxygenese (EC 1.13.1.12) was one of the first enzymes whose level was found to be regulated in vivo by adrenocortical hormones and its substrate, I-tryptophan (4). This enzyme was chosen for In vivo and in vitro studies on the mechanism of specific enzyme degradation because of its short half-life in vivo of 2.5 hour (5) compared to 3 days for, the average liver proteins (3); Its Inducibility by bydrocortisone and L-tryptophan; and its protection from degradation by L-tryptophan and DL- $\alpha$-methyltryptophan (6-8). The ability to inhibit its degradation in a specifle menner should help identify the physiological process, and the rapidity of its disappearance offered the opportunity to follow it over short time periods. The disappearance of the enzyne after its induction In liver was therefore followed in intact enimils, perfused livers, liver. slices and cell-free preparations, using a rapid assay of the enzyne protein. as an antigen (9), es well as activity assays of the several forms of the enzyme (10). 
MATERIALS AND METHODS

AIl rats used were inbred NADH adult males (200-250 g). Bilateral adrenalectomies were performed on some rats 5 -10 days before use. To increase the level of tryptophen oxygenase in livers, rats were treated with 0.25 mg hydrocortisone phosphate per $100 \mathrm{~g}$ body weight and sacrificed at 5 hours (with mean and SD of $16.2 \pm 6.4$ units/g liver), or treated with 2.5 rig hydrocortisone phosphate and $100 \mathrm{mg}$ L-tryptophan per $100 \mathrm{~g}$ body weight at 0 and 4 hours and sacrificed at 8 hours (with $38.1 \pm 24.4$ units/ g liver). The livers were promptly removed and used as donor livers for perfusion experiments, or chilled, and then sliced or homogenized for enzyme studies.

Liver slices were cut 0.5 mm thick on a stadie-Riggs microtome. Approxinately $250 \mathrm{mg}$ of slices and 2.25 ml of Eagles tissue mediug (Grand Island Biocheoical Co.) containing $0.01 \mathrm{M}$ phosphate buffer, pH 7.0 , were incubated at $37^{\circ}$ with gentle shaking in a stoppered 25 ml flask, with oxygen-carbon dioxide (95:5) as the gas phase. The final pH was 7.2-7.4. At the end of the incubation the entire flask contents were homogenized and centrifuged before assay. In sọe parallel experiments bomogenates and soluble fractions (25\%, w/v, final tissue concentration) were incubated like the slices, except that air replaced oxygen.

Liver homogenates were prepared with a glass teflon homogenizer in 2 volumes of Eagles tissue culture medium or in 3 volumes of $0.24 \mathrm{M} \mathrm{KCl-0.02} \mathrm{M}$ potassium phosphate buffer, $\mathrm{pH} 7.0$ (the standard $25 \%$ homogenate). All liver preparations were centrifuged for 40 min at $50,000 \mathrm{rpm}$ in a spinco kodel I, rotor 50 before the soluble fractions were assayed: The total tryptophan oxygenase activity and the proportion of holoenzyne were measured by the 
methods of Piras and Knox (10), with addition of 20 TIM GSH to the preincubazion (9); the tryptophan oxygenase antigen was determined by an imaunoinbibition titration previously described ( 9$)$. Other enzyme activities measured in whole liver homogenates were catalase (DC $1.11 .1 .6(21)$ ) and ornithine aminotransferase (EC 2.6.1.1.3 (12)); those in soluble fractions of livex were glucokinase (EC 2.7.1.2 (13)), hexokinase (EC 2.7.1.1 (13)) and tyrosine aminotransterase (EC 2.6.1.5 (14)).

Liver proteins were labeled in vivo with [U- $\left.{ }^{14} \mathrm{C}\right]$ leucine or with a mixture of uniformly labeled $\left[\mathrm{U}^{14} \mathrm{C}\right]$ amino acids (New England Nuclear). For maximum labeling of the soluble protein fraction and winimal counts in the trichloroecetic acid soluble fraction, $50 \mu \mathrm{C}$ was administered intravenously or intraperitoneally $2-3$ hours before sacrificing the rat. The total counts were obtained by dissolving 0.2 oll homogenates in $1.8 \mathrm{ml}$ of 100, formic actd or $0.5 \mathrm{ml}$ of Hyamine (Packard Instrument Corp.) and counting 0.2 ml in $10 \mathrm{ml}$ of Bray"s scintillation Pluld (15). The trichloroacetic acid soluble counts were neasured in duplicate aliquots of $0.5 \mathrm{ml}$ of the homogenate or soluble fraction, plus $0.5 \mathrm{ml}$ water and 3.0 onl 20 of trichloroacetic acid. 0.2-0.5 ml of this supernatant was counted in $10 \mathrm{ml}$ of Bray's scintillation fluid. Counts per min were corrected for quenching by means of an external standard on the Packard Tri-Carb seintilation counter.

To prepare labeled tryptophan oxygenase, mixed [u- ${ }^{14} \mathrm{C}$ ]amino acias ( $14 \mathrm{\mu C} / 100 \mathrm{~g}$ body weight) were injected intraperitaneally 1 hour before the end of an 8 hour hydrocortisone-tryptophan induction period. The enzyme was purified according to Knox et al, (16). The final specific activities were 36.8 units/mg protein and 324 cpm/unit of activity. 
Isolated liver perfusions were performed using the thethod of Miller et al. (17) as modified by Knox and Sharma (18). The perfusate contained $90 \mathrm{ml}$ of whole, heparinized rat blood, $60 \mathrm{ml}$ of Krebs-Ringer bicarbonate buffer containing $30 \mathrm{mg}$ of glucose, and $1.68 \mathrm{~g}$ bovine serum albumin (Armour, fraction $V$ ). Where indicated, the amino acid mixture (about 4 tiuses normal plasma leveis) described by Miller et al. (17) or kallette et al. (19), puromycin at $7 \mathrm{mg} / 150 \mathrm{al}$, or DL- $\alpha$-methyltryptophan at 1 mM were added to the perfusate. Iiver donors were rats treated earlier with hydrocortisone to induce high levels of tryptophan oxygenase.

\section{RESULTS}

Induction and Degradation of Tryptophan Oxygenese In Vivo-Time curves of the induction of tryptophan oxygenase activity by hydrocortisone and by the substrate, I-tryptophan, were constructed to determine the relative activity and antigen titer of the enzyme during its induction phase and its subsequent return to basal levels. In the ingrocortfsone induction, adrenalectorized rats were injected with $0.25 \mathrm{mg}$ hydrocortisone phosphate per $100 \mathrm{~B}$ body weight (20), a dose that has a limited period of action, and they vere killed at intervels for assay. The levels of tryptophan oxygenase activity and its antigen are plotted in Fig. $1 \mathrm{~A}$ as a function of time after the bydrocortisone treatment. At 2.5 hours the antigen reached a maximun level, while the activity had increased to only $50 \%$ of its maximun. Synthesis of tryptophan oxygenase protein recognizable as antigen may thus precede its conversion to a form which can be measured catalytically, but additional evidence for this is lacking. Boththe activity and antigen were at maxima at 5 hours. After that time, both decreased in parallel and approached the 
basal level between 9 and 12 hours, as previously found (20). The holoenzyme content was low and unchanging in these hydrocortisone inductions. The induction of tryptophan oxygenase by its substrate was aetermined in adrenalectorized rats Injected with 100 mg L-tryptophen per $100 \mathrm{~g}$ body weight. The total activity, holoenzyme, and the antigen were measured. As shown in Fig. IB, all these measures of the enzymte increased together to maximuta levels at 5 hours, and then decreased. Accumulation of the antigen did not precede the activity, as was found with hydrocortisone induction. However, after 5 hours the holoenzyue decreased faster than the total activity and the antigen. Aftar both kinds of induction, the parallel disappearance of enzyme measured by its activity or as an antigen demonstrated the occurrence of some sort of rapid enzyme degradation.

Loss of Tryptophan Oxygenase in Isolated Perfused Livers--Tryptophan oxygenase wes induced with hyarocortisone exactly es described for the experiraents in Fig. 14. At the height of the induction the livers vere transferred to the perfusion apparatus in order to follon the degradation phase in this simpler systent. The results are sumbarized in Table I. Enzyne ectivity and antigen decreased from the elevated levels initially present In the donor livers. The fall was fagter during control perfusions than it was in yivo. By way of comoarison, Bof of the peak Ievels persisted 2.5 hours later in the experiments in vivo shown in Fig. 1A. Eess than half this much remeined after 2.5 hour perfusion of the livers without added antino acids.

The rate was greatly reduced, to somewhat less than that seen in vivo, when a complete amino acid mixture mas added to the perfusate. Only a small amount of tryptophan was in these mixtures, and complete onission of it did not change these results. More tryptophan could be expected to promote 
continued synthesis and specifically to protect the enzyme. This was demonstrated with the unmetabolized analog, DL- $\alpha$-methyltryptophan. Perfusion wsth 1 aM edded $a$-methyltryptophan substantially prevented the disappearance of enzyme activity and antigen, and it was more effective in this regard than the mixture of amino acids. Since incluston of puromycin in the perfusate did not lessen the effect of $\alpha$-methyltryptophan, its main action did not appear to oe promotion of enzyme synthesis but protection. a-Methyltryptophan preserved the enzyme in $\underline{v i v g}(6,8)$ independently of its effect on enzyole synthesis, and appeered to do the same in this system.

Puromycin itself had a dramatic effect on degradation of the enzyme. Alone or in combination with the amino acid mixture it caused a precipitous lose of enzyme and antigen at a rate much faster than that gaen in vivo or in the control perfusion. This effect was blocked by a-methyltryptophan. Induced synthesis of tryptophan oxygenase under the wost favorable conditions (18) may not be rapid enough for this effect of puromycin to be ascribed solely to inhibition of protein synthesis.

In these several kinds of perfusions the changes of enzyme measured by Its activity and as antigen were aluays parallel. They appeared to represent changes in the rate of some kind of specific enzyme degradation like that seen in vivo.

A number of other enzymes were also measured in the perfused livers by activity assays to provide control information (Table I). Three of these are known to have relatively long half-lives in vivo: glucokinase, 11 hours (21); ornitbine axinotransferase, 20 hours (22); catalase, 1.25 days (23). Since these three and hexokinase did not change significantly during the relatively short perfusions, the changes of tryptophan oxygenase were to 
some extent specific. Tyrosine amfinotrensferase has a half life of 1.5 hours (24), even shorter than tryptophan oxygenase (2.5 hours), but it also did not decrease very much. Only in the perfusions containing puromycin did it decrease significantly, and o-methyltryptophan did not prevent this loss. To this extent the protection of tryptophan oxygenase in the perfusions by $\alpha$-usthyltryptophan was also spectiłc.

Loss of Tryptophan Oxygenase In Vitro--Disappearance of tryptophan oxygenase was measured in slices and cell-Pree preparations from livers of rats treated earlier with hydrocortisone and exanined at the height of the induction, following the same experimental design used with intact animals and perfused livers. Some of the rats were given $50 \mu \mathrm{C}\left[\mathrm{u}^{14}{ }^{14} \mathrm{C}\right.$ anino acids 2 or 3 hours before sacrifice to label their liver proteins. Table II describes the changes in tryptophan oxygenase activity and antigen, and the release of counts soluble in trichloroacetic acid, after incubation of these preparations for 2 hours. In each of these preparations there were significant and parellel losses of tryptophan oxygenase activity anò antigen that rere of the saras order of magnitude as were seen in perpused livers. An agino aptd mixture was included in sone or the Incuotions (in the Eagles medium), but it did not lessen the enzyme disapperarance like sonewhat larger anounts of arino acids did in the perfused livers. a-Methyltryptophan preserved the enzyme activity somewhat, but it regularly preserved the antigen to a significant extent in comparisons with incubations In its absence.

Irregular losses of the enzyole activity during these incubations were expectea and were not necessarily meaningful. Activity losses were always as great or greater than antigen losses, but otherwise the two were 
independent. However, the regular loss of significant amounts of the antigen, specificaliy prevented by $\alpha$-methyltryptophan in the medium indicated that some kiud of enzyms decradation occurrea to the same extant in these slices, homogenates and soluble fractions as in the intact organs. Ioss of tryptophan oxygetrase antigen was observed previously in slices but not in homogenates (8). Its occurrence even in the relatively simple soluble fraction was unexpected. The suspicion that the loss from the soluble fraction was not a proteolytic reaction was supported by sppplenenting this fraction with an excess of a protease-containing $2 y$ sosomal preparation (25) made according to Sawant et al. (26). Thls did not alter the rate of disappearance of the activity or entigen.

There was a significant release of counts from the labeled liver into the acid soluble fraction during incubation of the slices but not the homogenates. In relation to the injtial counts that were not soluble in trichloroacetic acid, this represented solubilization of 1 to $2 f^{\prime}$ of the labeled protein in 2 hours. Simpson (27) and Steinberg and Vaughan (28) reported similar rates of release in slices, and also did not detect the release in horogenates. o-Methyltryptophan did not affect this release, and so its preservation of tryptophan oxygenase antigen in the same experiments was not due to any general inhibition of protein breakdown.

More detailed studies of the disappearance of tryptophan oxygenase antigen were restricted to the soluble fractions, utilizing combinatione of the induced with non-induced preparations, or addition of puriffed enzyme to these preparations. The loss of the added, purified antigen was not afferent frow that of the endogenous antigen, and the losses were not different in induced or non-induced preparations .- when allowance was made 
for the fact that the loss was generally proportional to the initial antigen level (Fig. 2). As expected and as described in vivo, the time curve of the loss in these cell-free preparations was first order with respect to the antigen (Fig. 3 ). In these experiments the losses of total activity closely paralleled losses of antigen (half-lifo, $105 \mathrm{~min}$ ). This half-life in vitro of 1.75 hours can be compared to the half life of 2.5 hours measured in vivo $(5)$.

The small fraction of holoenzyme present in hydrocortisoneminduced preparations could not be measured with assurance, but its loss appeared to be more rapid than the main fraction of the enzyme (Fig. 3). However, this point was studied further with highly conjugated enzyme preparations from rat livers after induction for 5 hours with hydrocortisone plus tryptophan. Hemoglobin wes removed from the livers by saline perfusion before they were excised. Globin, $0.2 \mathrm{~kg}$ per ml, was added to the incubations to bind free heate. Antigen disappeared equally rapialy from these preparationa as from the unconjugated ones. Moreover, as long as no tryptophan was edded, there was an even more rapid conversion of the holoenzyme to apoenzyme (29). The conjugated state of the enzyme, which presented no obstacle to degradation of the enzyne in yivo (Fig. 1), also need not do so in vitro.

Degradation of Labeled Tryetophan Oxygenase In Vitro--Since purified enzyne added to non-induced liver preparations behaved in the same way as endogenous enzyme in induced preparations (Fig. 2), it was possible to study the process with addition of labeled enzyme (Table III). Disappearance of labeled and purified tryptophan oxygenase when added to homogenate and to the soluble fraction was similar to that observed with unlabeled, endogenous antigen. Approximately half was lost in 2 hours. $\alpha$-kethyltryptophan minimized this loss. The acid soluble counte released, however, bore no 
relation to the loss of antigen. Fewer counts vere released than predicted if the logt antigen became acid soluble. Althongh a-methyltryptophan preserved a significant fraction of the antigen, its addition did not significantly chenge the counts released. Nore counts were released in the homogenate than the soluble Praction, and more in the particulate fraction than the homgenate, as expected from their relative proteolytic activities ${ }^{(29)}$ This production of acid soluble counts was small and appeared to be the result of non-speciric proteolysis, gossibly coning in part fron labeled proteins that way have contaminated the tryptophan oxygenase preparation. The disappearance of antigen, even in the homgenate, did not appear to be significantiy related to proteolytic processes occurring during the period of these incubations.

To confirm this conclusion, the soluble fractions from the incubations in which antigen had disappeared were chromatographed on Sephadex G-100. Except for the small number of solubilized counts already mentioned, which appeared as amino acids or small peptides, the bulk of the labeled material had retained its high molecular weight and was eluted in the fractions tisth the active trygtophan oxygenase.

\section{DISCUSSION}

Enzyme degradation as studied here is an irreversible loss of activtty and antigenicity. This does not include loss of activiry due to accumulation of the tryptophan oxygenase apoenzyne or the oxidized holoenzyme, because these forms were routinely activated before assay by the procedure used (10). In addition, reactivation of enzyou after a prolonged incubation was about 100 greater with the $10 \mathrm{mM}$ glutathione added here to the preincubation 
mixture. Prequmably it protected a sulfhydryl group on the apoenzyme that was necessary for conjugation (10). Even so, irregular losses of activity could not be avoided in cell-free preparations. Except that these losses of ectivity were always as great or greater than loss of antigenicity, the two were not otherwise related. Loss of the antigen did not appear to be limited by a specific kind of ingctivation of the enzyme. Such a catalytically inactive antigen cannot be ruled out as an intermediate, however, since a spectes of this type appeared co accumulate temporarily during hydrocorticone induction of the enzynde (Fig. 1).

The antibodies used to messure the tryptophan oxygenase as an antigen by immunoinhibition were braad in latitude, since they reacted with apoand holoenzyme (9) as well as with various inactivated forms of the enzyme. The apoenzyme, which can be formed from the holoenzyme ropidly enough not to lifit the observed rate of antigen loss (29), would appear to be the specles thet is actually decraded and is protected from degradation by the substrate or substrate analog, not necessarily by conjugation.

Degradation of the enzyme is not cismically characterfzed by these criteria. The evidence is circumstantial that the same fnitial step occurs in the bierarchy of systems studied. Loss of the antigen in whole rats, perfused livers, slices of liver and cell-free liver preparations appeared, however, to occur by the same process because of the roughly similar rates in ell of these systems end the specific inhibjtion of the losses by $\alpha$-methyliryptophan in all of them. Special characteristics of the process in perfused livers were that the loss was slowed by mixed amino actis and accelerated by puromycin. Since the same mixture of amino acids was necessary for induced synthesis of tryptophan oxygenase in perfused livers (18), and puronycin 
Inbibits this same synthesis (30), the observed effects might be ascribed to changes in continued synthesis instead of changes in degradation. However, eynthesis or turnover of the enzyme is not known to occur rapldiy enough for this explanation. For example, the enzyme level was only maintained and not elevated by $\alpha$-tiethyltryptophan, as would be expected if there were both preservation plus on-going synthesis: However, neither of the two special cheracteristics of the loss from pexfused livers were seen in the sidpler systems. Degradation of the enzyme was characterized best in the simplest system, the soluble fraction of liver. In addition to inhibition of the loss dy Q-methyltryptophan (and E-trifptophan), the rate of loss was proportional to the concentration of enzyme present. It was also independent of the physiological stste of the liver from which the fraction was obtained, since added purified enzyne behaved in the same way aa endogenous enzyme. The loss was not dependent upon the proteolytic activity in liver that is mainly located in the particulate fractions (25). The loss was, in fact, unacconpenied by any sienificant proteolysis during the 2 hour periods studied. The characteristics of the apparent first step in this enzyme degradation are, therefore, akin to some form of deneturation of the protein. Its prevention by the presence of substrate or its analog could result from $s$ tabilizing a certain configuration of the enzyme protein. When unstabla, the catalytically and ontigenlcally ingctive species formed could be like that postulated by Paulus and Alperg (31) on other grounds, i.e.., an obligatory intermediate in the biosynthesis of this and other ollgomeric enzycs that are subject to "preconditioning" by allosteric ligands. 


\section{ACKNOWLEDGNENT}

We are grateful to Drs. Lea Reshef and Agnes Tan Yip who contributed some of the experiments in Table II.

\section{FOOTHOTES}

*This investigation was supported bX USPHS Training Grant GM 00451

(to J. B. L.); by USPHS Grants AM 00567 and Research Career Award AM-K6-2018 of the National Institute of Arthritis and Metabolic Diseases; and by United States Atomic Energy Comalssion Contract AP(11-1)-3085 with the New England Deaconess Hospital.

fPresent address: Department of Physiology, Harvard Medical school, Boston, Massachusetts 02115 . 


\section{REFTRENCES}

1. Schoenheimer, R. (1942) The dynamic state of body constituents, Harvara Unir. Press, Cambridge.

2. Schiuke, R. T., and Doyle, D. (1970) Ann. Rev. Biochem., 39, 930.

3. Schimke, R. T. (1970) Mammalian Protein Metab., 4, 177.

4. Knox, W. E. (1951) Brit. J. Exptl. Fathol. , 32, 462.

5. Feigelson, P., Dashman, T., and Nargolis, F. (1959) Arch. Biochem. Biophys., $85,478$.

6. Knox, W. E., and Piras, H. H. (1967) J. Biol. Chem., 242, 2959.

7. Schimke, R. T., Sweeney, E. H., and Berlin, C. If. (1965) J. Biol. Chem., $240,322$.

8. Schimke, R. T., Sweeney, E. W., and Berlin, C. H. (1965) J. Biol. Chem*, $240,4609$.

9. Ii, J. B., and Knox, W. E. Accompanying manuscript.

10. Piras, M. M. and Knox, w. E. (1967) J. Biol. Gher., 242, 2932.

11. Rechetgl, M. and Heston, W. E. (1963) I. fat. Cancer Inst., 30, 855.

12. Herzfeld, A., and Knox, H. E. (1968) J. Biol. Chen., 243, 3327.

13. Jandar, S. C., and Greengerd, 0. (1970) J. Blol. Che료. , 245, 2779.

14. Iin, E. C. C., Pitt, B. M., Civen, M., and Knox, W. E. (1950) J. Btol. Chen., 233, 668 .

15. Bray, G. A. (1960) Anal. Blochen., 1, 279.

16. Knox, W. E., Yip, A., and Reshef, L. (1970) Methods Enzymol., 17, 415.

17. Niller, I. I., Bly, C. G., Watson, M. L., and Bale, W. F. (1951) J. Expt1. Med., $94,431$.

18. Knok, w. E., and Sharma, C. (1968) Enzynol. Biol. chin., 9, 21. 
19. Mallette, L. E., Exton, J. H., and Park, C. R. (1969) J. Biol. Chem., $244,5713$.

20. Knox, W. E., Piras, M. M., and Tokuyama, K. (1966) Enzytiol. Biol. Clin., 7. 1 .

21. Freedland, R. A. (1968) Life \$ci., 7, 499.

22. Stilek, R. W., Rexroth, A. K., and Strange, J. I. (1966) J. Btol. Chem., 243,3581 .

23. Recheigl, M., Jr. (2968) in H. A. Sober (Editor), Handbook of biochenistry,

p. K-14, The Chemical Rubber Co., Cleveland.

24. Kennay, F. T. (1967) Science, 156, 525.

25. de Duve, c., and Wattiaux, R. (1967) Ann. Rev. Fhysiol., 28, 435.

26. Sastant, P. L., Shibko, S., Kutata, U. S., and Tappel, A. I. (1964)

Biochim. Biophys. Acta, 85, 82.

27. Simpson, H. V. (1953), J. Biol. chem., 201, 143.

28. Stejnberg, D., and Vaughan, M. (1956) Arch. Biochen. Biophys. , 65, 93.

29. Li, J. B. (1971) Fh.D. Thesis, Harvard University, Cambridge.

30. Goldstein, L., Stella, E. J., and Knox, W. E. (1962) I. Btol. Cbem., 237, 1723.

31. Paulue, H., and Alpers, J. B. (1971) Enzymes, 12, 384. 


\section{LESERDS}

FIG. 1. Changes of tryptophan oxygenase activity and its antigen after hydrocortisone and L-tryptophan treatments. Adrenalectomized male rats were injected intraperitoneally with either $0.25 \mathrm{mg}$ hydrocortisone phosphate (A) or 100 mis L-tryptophan (B) per 100 g body weight at 0 hour. Tryptophan oxygenase total activity (--0--), holoenzyme (-nt-) and antigen (--X--) were measured. Units are umoles/hour/g liver or the equivalent antigen unts. The vertical bars represent 1 standard error of the mean of 3-13 rats.

FIG. 2. Initial and final amounts of tryptophan oxygensse antigen in Incubated soluble liver fractions. Diffexent initial levels of tryptophan oxygenase wers obtained by combining soluble liver fractions (25t) frow hydrocortisone-induced and non-induced rats, and by additions of partially purified enzyme to both types of preparations. All were incubeted for 2 hours at $37^{\circ}$, and the tryptophan oxygenase entigen ( $\mathrm{TO}_{\mathrm{AC}}$ ) per ml neasured before and after the incubation.

FIG. 3. Ioss of tryptophan oxygerase, its antigen and holoenzyme during incubation. Soluble fractions of hydrocortisone-induced livers were inchbated at $37^{\circ}$, and the antifen $(x)$, total activity (o) and holoenzyme (A) vere measured at various time points. Measurements bave been divided by their respective inftial amounts to normalize them to percent of the initial values. Each point is the average of several values determined in different experiments. The time $\left(t_{2 / 2}\right)$ for half of the inttial amounts to disappear for antigen and total ectivity was $105 \mathrm{~min}$, and for holoenzye 20 min. 


\section{TABLE I}

\section{Loss of tryptophan oxygenase in isolated perfused livex}

Donor livers were from rats induced with hydrocortisone for $3-5$ hours before perfusion. 'Additions to the control perfusate were; amino acid mixture (either Miller et al. (17) or Mallette et gl. (19)), $7 \mathrm{mg}$ of puromycin and $1 \mathrm{MM} \alpha$-methyltryptophan. Blopsies of the liver were taken at 0 and $2.5 \mathrm{hours}$ and homogenates were assayed for ornthine aminotransferase (OAT) and catalase (Cat.); the soluble fraction was assayed for tryptophan oxygenase (TO) and its antigen (TO ${ }_{A G}$ ), tyrosine aminotransferase (TAT), Glucokinase (GK) and hexokinase (HK). The values are percent of the initial smounts. Alz results are averages of several perfusions.

Perfusion

Percent of the Initial Value (100) after 2.5 hour Perfusion

Control

+ Ardino Acias

$\begin{array}{rrrrrrr}\text { TO } & \text { TO }_{\text {AG }} & \text { TAT } & \text { GK } & \text { HK } & \text { OAT } & \text { Cat. } \\ 37 & 30 & 140 & 84 & 91 & 81 & 96 \\ 87 & 81 & 111 & 98 & 114 & & \\ 85 & 86 & 93 & & & & \\ 6 & 5 & 72 & & & & \\ 107 & 84 & 53 a & & & & \end{array}$

$\underline{a}$ Decreasc occurred only with puromycin present. 


\section{Ioss of tryptophan oxygenase activity and thtigen and proteolysis of libeled protein}

\section{in liver sifices, homogenates and soluble fractions}

Assays of tryptophan oxygenase (TO) activity and as antigen before and after incubation for 2 hours at $37^{\circ}$ are expressed as percent of the intial values. TCA soluble counts released fron prelabeled liver prepaxations are expressed as percent of the initial ratio of soluble to total cpn. The means \pm standara deviation are given with the number of experiments in parentheses. All preparations of liver were derived from hydrocortisone-induced rats with $16.2 \pm 6.4$ units/g liver. Slices, honogenates and the first solubie fraction (a) were incubated in Eagles medium and in oxygen-carbon dioxide strosphere. The second soluble fraction (b) values were incubated in kCl-phosphate buffer, pH 7, with air as the gas phase.

\begin{tabular}{|c|c|c|c|c|c|c|}
\hline Liver & & 2 Hour Incubat & & 2 Kour Incu & Lon +5 m $\alpha$ - & tryptophan \\
\hline Preparation & To Activity & TP Antigen & TCA Sol: cpm & To Activity & To Antigen & TCA SOL. cpm \\
\hline slices & $33 \pm 15$ (19) & $32 \pm 10(23)$ & $132 \pm 35(6)$ & $56 \pm 23(9)$ & $77 \pm 23(12)$ & $125 \pm 28(6)$ \\
\hline Homogenate (a) & $15 \pm 9(16)$ & $21 \pm 6(6)$ & $109 \pm 16(6)$ & $17 \pm 14(4)$ & $58 \pm 19$ (4) & $99 \pm 10(6)$ \\
\hline Horogenate (b) & 43 & 50 & --- & 37 & 69 & --- \\
\hline $\begin{array}{l}\text { Soluble } \\
\text { iraction (a) }\end{array}$ & $35 \pm 9(11)$ & $23 \pm 7(11)$ & --- & $68 \pm 19(3)$ & $73 \pm 21(3)$ & -- \\
\hline $\begin{array}{l}\text { Soluble } \\
\text { fraction (b) }\end{array}$ & 33 & 38 & --- & 96 & 101 & $=-$ \\
\hline
\end{tabular}




\section{TABEE III}

Incubation of ${ }^{\left[\mathrm{Un}^{1 \mathrm{l}} \mathrm{c}\right] \text { ] labeled }}$ tryptophan oxygenase

Tryptophan oxygenase was purified from livers of rats given [u- ${ }^{14} \mathrm{c}$ ] amino acid mixture (36.8 units/mg protein and $324 \mathrm{cpm} /$ unit). For stability it was stored with $5 \mathrm{mM}$ L-tryptophan at $\mathrm{pH} 8$ in $0.2 \mathrm{M}$ potassium phosphate, and passed through Sephadex $6-25$ and neutralized juet prior to addition to equivalent amounts of homogenate, soluble and particulate fractions from noninduced rat livers. Units (umoles/hour) of tryptophan oxygenase (To) activity and antigen $\left(\mathrm{TO}_{\mathrm{AG}}\right)$ which disappeared, and the counts soluble in $20 \%$ trichloroecetic acid which were released per ml of incubated mikture are compared with the counts expected if the enzyme lost became acid-soluble.

Loss in $\underline{\text { 2 hour }}$

Preparation

Homogenate

Homogenate $+\alpha$. methyltryptophan

Soluble fraction

Soluble fraction + $\alpha$-methyltryptophan

Particulate fraction

Pariculate iraction + $\alpha$-methyltryptophan
1. Incubation

TiD $\quad T O_{A G}$ (und:ts/ml)

$7.24 \quad 5.43$

$5.34 \quad(-0.50)$

4. 04

1.95

4.10

$-$

0.10
1328

Acid-Soluble Counts

Releaşa

Expected Found

(cpm/mL)

$1760 \quad 48$

32

13

16

323

32 

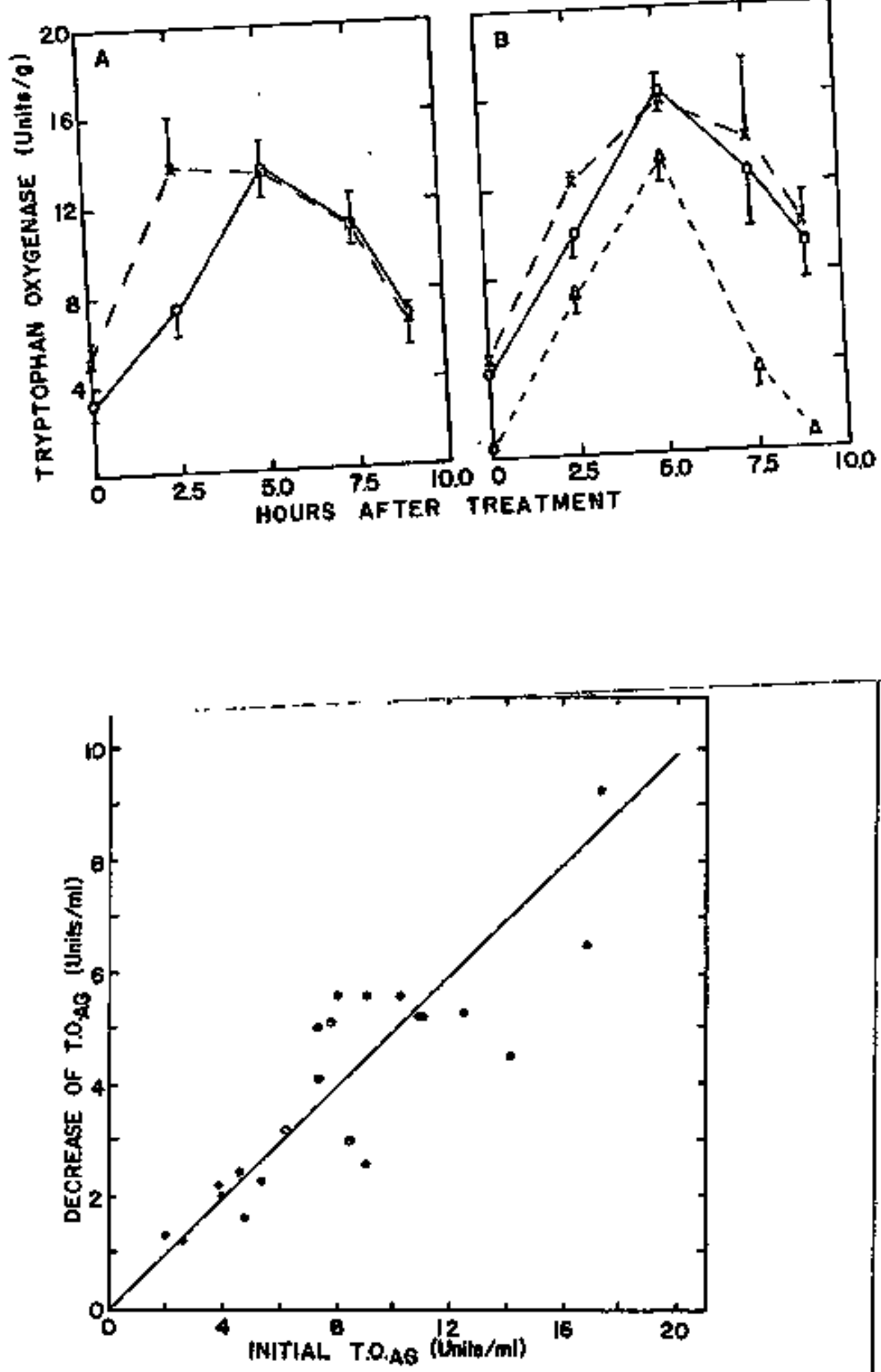


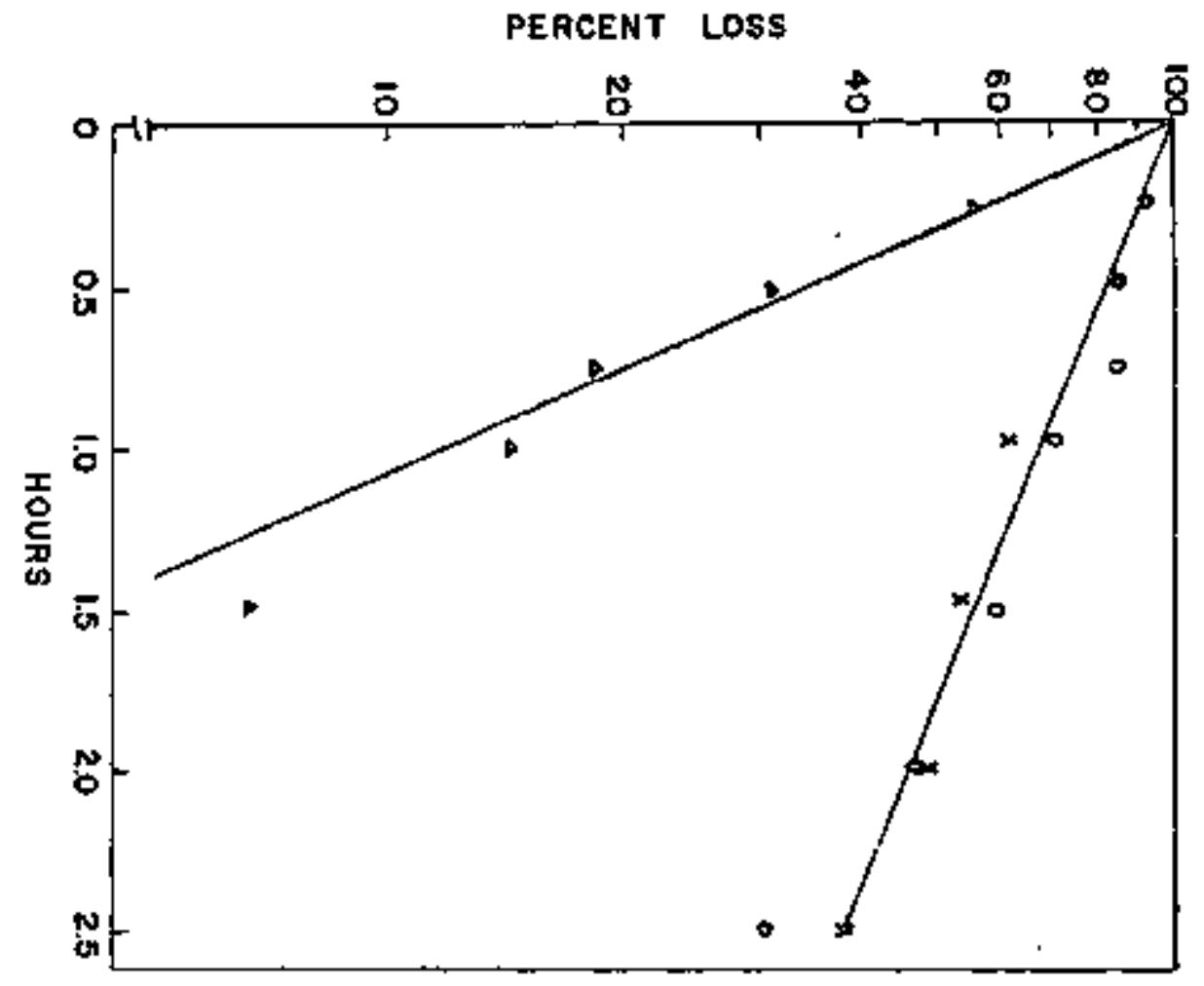

